Ann. Biol. anim. Bioch. Biophys., 1979, 19 (5), 1475-1481.

\title{
Follicular populations in the ewe under different gonadotrophin levels
}

\author{
by L. P. CAHILL ${ }^{(1)}$, J. DUFOUR $\left({ }^{2}\right)$
}

Station de Physiologie de la Reproduction, I.N.R.A. Nouzilly 37380 Monnaie, France.

\begin{abstract}
Summary. Successful ovarian stimulation depends upon two factors (i) the number of follicles in the growth phase and (ii) the speed at which these follicles are growing.

These two parameters, that is the number and growth rate of follicles in the growth phase were established in two breeds of sheep, which differ widely in their ovulation rate, and some hormonal influences on these parameters were demonstrated. The number of antral follicles was found to be immediately reliant on gonadotrophic support and a study of hormonal levels during the cycle and follicular populations at the following œstrus found that the magnitude of the second peak of FSH on day 2 of the cycle was correlated with the number of antral follicles present some 17 days lafer. Thus when 500 IU of PMSG was injected on day 2 of the cycle there were significantly more twin-ovulating ewes at the following œstrus but there were no over-stimulated ewes that-are normally observed following the normal PMSG treatment.

It is concluded that PMSG treatment early in the cycle may be a worth while approach to induce twin ovulations.
\end{abstract}

The success of ovarian stimulation depends on the optimum number of follicles that are able to be stimulated to ovulate being present at the time that the stimulating treatment is administered. The number of follicles present at such a given stage is dependent upon : (i) the number of follicles in the growth phase and (ii) the speed with which follicles grow throughout this phase.

This paper proposes to establish, firstly, the number and growth rate of follicles throughout the growth phase in the adult sheep and secondly to investigate some hormonal factors which are associated with such follicular parameters.

\section{Follicular populations in ewes of different ovulation rates.}

The initial experiment in this study was to establish the total number of follicles in the adult sheep ovary during the breeding season (Cahill, Mariana and Mauléon,

(1) On study leave from : A.R.I. Werribee, Victoria, Australia.

(2) Centre de Recherche, Lennoxville, Quebec, Canada. 
1979). This was carried out on two different breeds of sheep which differ widely in their ovulation rate - the Romanov and the lle-de-France breeds with mean ovulation rates of 3.1 and 1.6 respectively. The total ovarian follicular population was divided into two parts; small follicles which included all follicles with two or less layers of granulosa cells and all larger follicles. It was found that in the Romanov breed there were significantly less small follicles but significantly more large follicles at all follicular sizes throughout the growth phase as schematically shown in text-figure 1. Within the lle-de-France breed a comparison of single and twin ovulations showed the same profile with the ewes having the higher ovulation rate having more large follicles. The difference in ovulation rate observed in these normal cycling animals was not able to be explained by a difference in atresia as there was no difference between breeds in the number or proportion of atretic follicles in the breed with the higher ovulation rate.

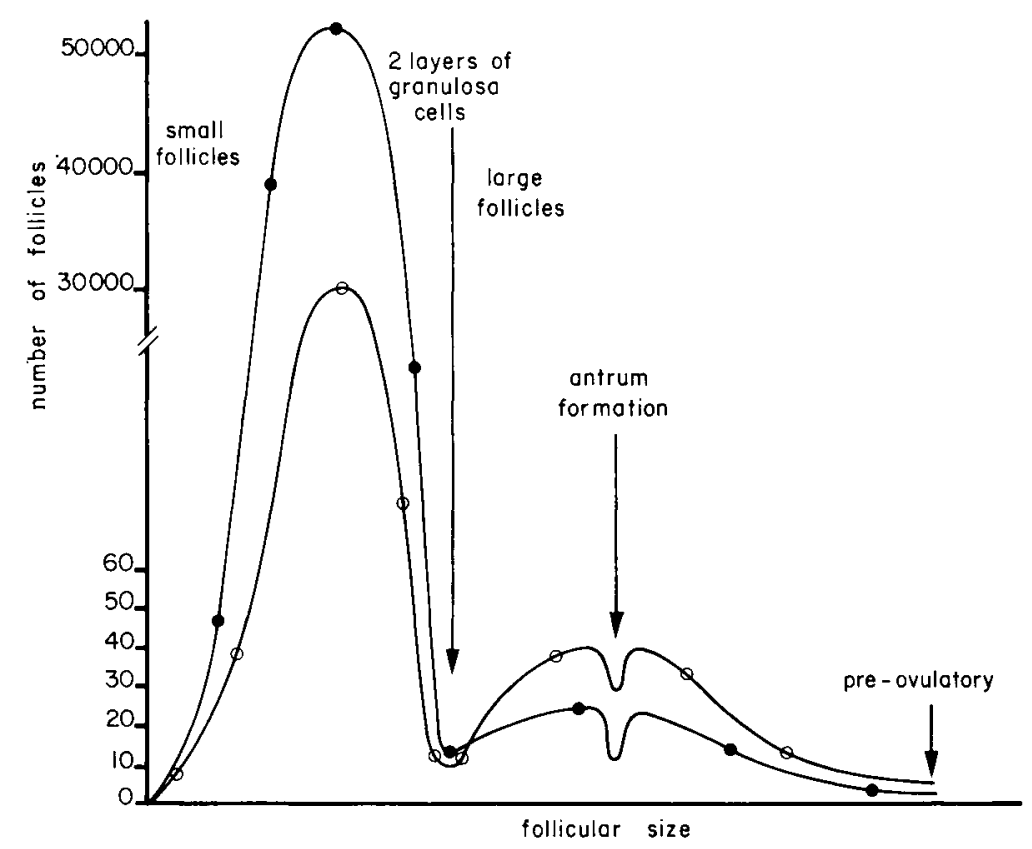

Text-FIG. 1. - Schematic diagram of the fotal ovorian follicular population in ewes of high ( - - ) and low ovulation rates (- -

(from Cahill, Mariana and Mauléon, 1979)

These results explain the findings of Bindon, Ch'ang and Turner (1971) and Smith (1976) who, following treatment of high and low fecundity ewes with PMSG, found a higher response in the high fecundity ewes. Our work shows that such high fecundity ewes would have more follicles in the growth phase than the low fecundity ewes, and thus more follicles available to be stimulated. 


\section{Follicular growth rafes.}

The second experiment in this study was designed to study the chronology of follicular growth of the large follicles (i.e. from three or more layers of granulosa cells up to the preovulatory stage). The method used was to study the mitotic index of the granulosa cells at times 0 and 2 hrs following colchicine treatment which blocks the mitotic process at the metaphase - anaphase region. Using the formula presented by Puck and Steffen (1963) the duration of mitosis and the time to pass through the growth phase can be calculated. The influence of factors such as cycle (day 0 vs. day 7 ), season (oestrus vs. anoestrus) and breed (Romanov vs. lle-de-France) were investigated (Cahill and Mauléon, 1979). However, very large variations were found to exist, per class, between animals in their follicular growth rates. These between animal variations were so great in respect to the number of ovaries physically able to be studied, that no significant differences could be found in the follicular growth rates at the different times of the cycle, season or between different breeds studied. The overall mean time (neglecting the between animal variation) for follicles to pass from three layers of granulosa cells to the pre-ovulatory stage was found to be about 6 months (173 days) (table 1) however, the major part of this time was spent in the pre-antral stage (130 days). The time to pass from when antrum formation commences to the pre-ovulatory stage was 43 days which agrees with the work of Turnbull, Braden and Mattner (1977). Another important finding of this particular sludy was the correlation found between the number of follicles in a class and the growth rate (mitotic index) of follicles in that class. Highly significant negative correlations were found between the number of follicles and follicular growth rate per class for a given animal. It is possible that an ovary is able to adjust the number of follicles in a given class by adjusting the follicular growth rate which would explain the large between animal variation we found in our study.

TABLE 1

The mean doubling time and time for a follicle to pass through various follicular classes for eight Romanov and eight lle-de-France ewes

\begin{tabular}{|c|c|c|c|c|c|c|c|}
\hline $\begin{array}{l}\text { Follicle class } \\
\text { diam. }(\mathrm{mm})\end{array}$ & $0.056-0.112$ & $0.113-0.200$ & $0.201-0.356$ & $0.357-0.634$ & $0.635-1.128$ & $1.129-2.006$ & $2.007-4.000$ \\
\hline $\begin{array}{r}\text { Doubling time } \\
\text { (hours) } \ldots . . .\end{array}$ & 831 & 520 & 244 & 99.0 & 66.0 & 71.6 & 86.5 \\
\hline $\begin{array}{r}\text { Time to pass } \\
\text { through class } \\
\text { (days) } \ldots . .\end{array}$ & 78 & 52 & 19.3 & 8.1 & 3.8 & 6.1 & 7.3 \\
\hline
\end{tabular}

(from Cahill and Mauléon, 1979) 
And also, we arrive at the curious situation that to control ovarian stimulation, the two factors which we need to manipulate (i.e. follicle numbers and growth rate) are correlated to one another so if we change one we automatically change the other.

\section{Hormone-follicle relationships.}

Let us now look at some of the hormonal influences on follicular populations and in the first study we altered the ovarian-pituitary equilibrium and studied the follicular populations.

a) Influence of hypophysectomy and hemicastration.

At day 10 of the cycle, 5 adult ewes were hypophysectomized and 4 days later the first ovary was removed and 70 days later the other ovary was removed. In another 5 ewes following a sham operation on day 10 of the cycle, one ovary was removed 4 days later (day 14) and on day 14 of the fourth subsequent cycle (about 70 days later) the other ovary was removed. It must be noted that the long term groups (ovaries removed at day 70) were hemicastrated ewes with and without a pituitary (Dufour, Cahill and Mauléon, 1979).

Thus we altered the ovarian-pituitary equilibrium in one case by hypophysectomy which can be considered as producing an animal of very low levels of gonadotrophins as incomplete hypophysectomy and regeneration of the remaining cells can not be disregarded. At four days following hypophysectomy there were no changes in the pre-antral follicle population whilst at 70 days following treatment there were significantly fewer pre-antral follicles although none were atretic. Thus the re-stocking of follicles from the primordial reserve of follicles was occurring at a slower rate than the depletion of follicles as they left to enter the antral phase. For antral follicles even at four days following hypophysectomy all follicles larger than $2.01 \mathrm{~mm}$ in diameter were atretic and especially at 70 days after treatment there was a large decrease in the number of antral follicles.

The second way we altered the ovarian-pituitary equilibrium was to hemicastrate the animals - such a treatment would have a variety of effects resulting in initially an increase in gonadotrophins during $6 \mathrm{hrs}$ (Findlay and Cumming, 1977), a halving of the entire follicle population and a changing of the feed-back mechanism. At 70 days following hemicastration the population of the pre-antral follicles was greatly increased especially in the smaller pre-antral follicles, thus the ovary was in the process of re-stocking its supply of pre-antral follicles to compensate for the loss of one ovary. There were also more antral follicles but this difference was not significant.

This study shows that the antral follicles are immediately reliant on gonadotrophc support and that removal of such support immediately results in atresia. However the pre-antral follicles are a more stable population that is certainly influenced by gonadotrophins but such influence can only be seen in the long term. This was clearly evident following hemicastration where at last we have been able to alter the population of pre-antral follicles by a treatment but the effects were only seen after a considerable period of time had elapsed (70 days in this study). 
Follicular growth rates were also studied in this experiment in a similar manner to that used in the previous experiment. The mean mitotic index was found to decrease slightly in pre-antral follicles with a more evident decrease in the antral follicles following hypophysectomy. However, the parameter which appeared to be the most sensitive to the treatment applied was the estimated number of active follicles per ovary (which was calculated from the proportion, per class, of follicles where one mitotic figure per largest cross-section was seen, multiplied by the number of follicles in that class). Following long term hypophysectomy the estimated number of active follicles decreased for both pre-antral and antral follicles (day 4 vs. day 70 in table 2) whilst it increased for both follicle types following long term hemicastration. This agrees with the work of Greenwald (1962) which suggested that for a given class of follicles there are follicles that are actively growing and others in a type of reserve which are called upon as required. Here again we have this association between the number of follicles present and their growth rate and here we have shown that this association can be manipulated by hormonal factors.

TABLE 2

The effect of hypophysectomy (at 4 and 70 days post operation) and hemicastration (at 70 days post operation) on the mitotic index (M.I.) and the estimated number of active follicles (Proportion of active follicles per class $\times$ Number of follicles per class) per ovary

\begin{tabular}{|c|c|c|c|c|c|}
\hline & & & & Day $70(\mathrm{H}$ & i-castrate) \\
\hline & cles & & & $41(0,100)$ & \\
\hline Pre-Antral & $\begin{array}{l}\text { Control } \ldots . \\
\text { Hypox } \ldots .\end{array}$ & $\begin{array}{l}0.14 \pm 0.04 \\
0.23 \pm 0.04\end{array}$ & $\begin{array}{l}33.6 \pm 8.2 \\
51.9 \pm 6.2\end{array}$ & $\begin{array}{l}0.20 \pm 0.02 \\
0.10 \pm 0.04\end{array}$ & $\begin{array}{l}63.6 \pm 7.4 \\
12.5 \pm 2.9\end{array}$ \\
\hline Antral & $\begin{array}{l}\text { Control } \ldots . \\
\text { Hypox } . . .\end{array}$ & $\begin{array}{l}1.69 \pm 0.09 \\
1.36 \pm 0.10\end{array}$ & $\begin{array}{l}50.1 \pm 4.7 \\
50.8 \pm 6.6\end{array}$ & $\begin{array}{l}1.41 \pm 0.08 \\
0.84 \pm 0.21\end{array}$ & $\begin{array}{l}64.2 \pm 7.9 \\
26.4 \pm 6.4\end{array}$ \\
\hline
\end{tabular}

b) Correlations befween hormonal and follicular parameters in cyclic animals.

An attempt to correlate hormonal and follicular parameters was also carried out in the normal cyclic adult ewes. Throughout the cycle prior to ovariectomy the levels of LH, FSH and prolactin were measured in Romanov and Ile-de-France ewes and correlations between the number of follicles and hormonal parameters were calculated (Cahill, ef al., 1979). Unfortunately due to the small number of animals studied, both breeds were pooled together for such calculations. Surprisingly, concerning LH parameters, both the peak and mean daily levels throughout the cycle were not found to be correlated with the number of follicles in any class of follicles. The prooestrus rise in prolactin was found to be correlated with the number of both antral and pre-antral follicles - whether prolactin is acting directly on the pre-antral follicles remains unknown. FSH was found to have 2 peaks as has been demonstrated previously in the sheep (L'Hermite ef al., 1972) - the first peak is coincident with the LH peak 
whilst the second peak occurred 20-30 hrs after the LH peak. The first FSH peak was not correlated with any follicular parameter but the second FSH peak was correlated with the number of antral follicles present at the following oestrus some 17 days later. This model agrees exactly with the model presented by Greenwald (1962) who suggested that the peak of FSH around the time of oestrus may be responsible for recruiting a further cohort of follicles to develop in the subsequent cycle.

\section{Gonadotrophic stimulation on day 2 of cycle.}

In order to test the applicability of our findings we endeavoured to stimulate the ewe at the same time as the second FSH peak (i.e. on day 2 of the cycle) and to see the effect on the ovulation rate. This experiment was carried out in sheep at the A.R.I., Werribee, Australia, in collaboration with Dr. Cumming. On Day 2 of the cycle ewes were injected with 500 IU of PMSG to endeavour to change the antral follicular population and thereby more follicles develop towards ovulation. PMSG was also injected on both days 2 and 12 in order to stimulate the growth of more antral follicles but then the second injection was to protect these follicles from atresia. In table 3 the results of this experiment show that PMSG given on day 2 significantly increased the proportion of twin ovulating ewes compared to the control group (Group 1 vs. 2) without having ewes with excessively high ovulation rates. When the same quantity of PMSG (500 IU) was given on day 12 (Group 3) there was also a superovulatory response but also included the extremes values normally observed after PMSG injection. When PMSG was given on both days 2 and 12, it obviously resulted in an overstimulation.

TABLE 3

The effect of 500 IU of PMSG on Day 2, Day 12 and Days $2+12$ on the mean ovulation rate

\begin{tabular}{|c|c|c|c|c|c|c|c|}
\hline \multirow{2}{*}{ Group } & \multicolumn{3}{|c|}{$\begin{array}{l}\text { Treatments } \\
\text { (PMSG IU) }\end{array}$} & \multirow{2}{*}{ No ewes } & \multirow{2}{*}{$\begin{array}{c}\text { Ovulation } \\
\text { rate }\end{array}$} & \multicolumn{2}{|c|}{ No ewes } \\
\hline & Day 2 & & Day 12 & & & 2 ovulations & $>3$ ovulations \\
\hline $\begin{array}{l}1 \\
2 \\
3 \\
4\end{array}$ & $\begin{array}{r}0 \\
500 \\
0 \\
500\end{array}$ & $\begin{array}{l}+ \\
+ \\
+ \\
+\end{array}$ & $\begin{array}{r}0 \\
0 \\
500 \\
500\end{array}$ & $\begin{array}{l}33 \\
37 \\
32 \\
37\end{array}$ & $\begin{array}{l}1.15 \\
1.38 \\
1.81 \\
1.69\end{array}$ & $\begin{array}{r}5 \\
14 \\
17 \\
5\end{array}$ & $\begin{array}{l}0 \\
0 \\
5 \\
4\end{array}$ \\
\hline
\end{tabular}

In collaboration with Dr. Cumming, ARI, Werribee, Australia.

Thus this pilot experiment suggests that perhaps stimulation of the animal early in the cycle with PMSG around day 2 in order to enhance the FSH surge may be applicable in ovarian stimulation in the field. It is possible that if the number of antral follicles can be elevated by such a gonadotrophin treatment early in the cycle, the ewe herself may be able to reduce, by atresia, the undesirable extreme values so often seen following PMSG treatment, and thus result in a constant level of 2 or 3 ovu- 
lations according to the dose. Further studies both in the field and in the laboratory are warranted to elucidate the influence of gonadotrophic stimulation early in the cycle.

EEC Seminar on « Ovarian stimulation and egg quality in mammals », Luynes, France, octobre 1978.

Acknowledgements. - The authors wish to acknowledge the contributions and collaboration of Drs. P. Mauléon and I. A. Cumming towards this study.

Résumé. Une stimulation ovarienne correcte dépend de deux facteurs : (1) le nombre de follicules dans la phase de croissance et (2) la vitesse de croissance de ces follicules.

Ces deux paramètres ont été mesurés chez deux races ovines ayant des taux d'ovulation frès différents ef quelques influences hormonales ont été démontrées. Le nombre de follicules à antrum est fonction de la secrétion des hormones gonadotropes. L'étude des niveaux hormonaux pendant le cycle montre que la magnitude du pic de FSH au $2^{2}$ jour du cycle est corrélée positivement avec le nombre de follicules à antrum présents 17 jours plus tard.

Une injection de 500 Ul de PMSG au deuxième jour du cycle entraîne une augmentation significative du nombre de brebis ayant deux ovulations à l'cestrus suivant sans que soient observés les cas de stimulation excessive normalement notés après le traitement classique de PMSG.

II semble donc qu'un traitement PMSG au début du cycle soit un moyen intéressant pour induire une polyovulation modérée.

\section{References}

BINDON B. M., CH'ANG T. S., TURNER H. N., 1971. Ovarian response to gonadotrophin by merino ewes selected for fecundity. Aust. J. Agric. Res., 22, 809-820.

CAHILL L. P., MARIANA J. C., MAULÉON P., 1979. Total ovarian follicular populations in ewes of high and low ovulation rates. J. Reprod. Fert., 55, 27-36.

CAHILL L. P., MAULÉON P., 1979. Effects of season, cycle and breed on follicular populations in sheep. J. Reprod. Fert. (in press).

CAHILL L. P., SAUMANDE J., RAVAULT J. P., BLANCM., THIMONIER J., MARIANA J. C., MAULÉON P., 1979. Hormonal and follicular parameters in ewes of high and low ovulation rates. J. Reprod. Fert. (in press).

DUFOUR J., CAHILL L. P., MAULÉON P., 1979. Short and long ferm effects of hypophysectomy and hemicastration on ovarian follicular populations in sheep. J. Reprod. Fert. (in press).

FINDLAY J. K., CUMMING I. A., 1977. The effects of unilateral ovariectomy on plasma gonadotrophin levels, estrus and ovulation rate in the sheep. Biol. Reprod., 17, 178-183.

L'HERMITE M., NISWENDER G. D., REICHERT L. E., MIDGLEY A. R., 1972. Serum follicle-stimulation hormone in sheep as measured by radioimmunoassay. Biol. Reprod., 6, 325-332.

GREENWALD G. S., 1962. Analysis of superovulation in the adult hamster. Endocrinology, 71, 378389.

PUCK T. T., STEFFEN J., 1963. Life cycle analysis of mammalian cells. I.A method for localizing metabolic events within the life cycle and its application to the action of colcemide and sublethal doses of $X$-irradiation. Biophys. J., 3, 379-397.

SMITH J. F., 1976. Selection for fertility and response to PMSG in Romney ewes. Proc. N. Z. Soc. Anim. Prod., 36, 247-251.

TURNBULL K. E., BRADEN A. W. H., MATTNER P. E., 1977. The pattern of follicular growth and atresia in the ovine ovary. Aust. J. biol. Sci., 30, 229-241. 